\title{
THE GENUS FREYCINETIA (PANDANACEAE) IN NEW GUINEA (PART 4)
}

\author{
KIM-LANG HUYNH \\ Evolutive Botany Division, Botanical Institute, University of Neuchâtel, \\ CH-2007 Neuchâtel, Switzerland
}

\begin{abstract}
SUMMARY
Seventeen new species of Freycinetia Gaudich. are described from groups of islands of New Guinea: Freycinetia admiraltiensis, $F$. amoena, $F$. formosula, $F$. granulata, $F$. lanceolata, $F$. nakanaiensis, F. novobritannica (Bismarck Archipelago), F. relegata, $F$. rossellana (Louisiade Archipelago), $F$. angusta, $F$. awaiarensis, $F$. boluboluensis, $F$. fergussonensis, $F$. goodenoughensis, $F$ lenifolia, $F$. normanbyensis (D'Entrecasteaux Islands), and $F$. woodlarkensis (Woodlark Island). Specific characters from both gross morphology and anatomy of fruits, seeds, and leaf auricles are used for the description.
\end{abstract}

Key words: Freycinetia, Pandanaceae, New Guinea, taxonomy.

\section{INTRODUCTION}

The present paper describes unknown species of Freycinetia Gaudich. from some groups of islands of New Guinea: the Bismarck Archipelago (Manus Is., New Ireland, New Britain), the Louisiade Archipelago (Sudest Is., Rossel Is.), D'Entrecasteaux Islands (Goodenough Is., Fergusson Is., Normanby Is.), and Woodlark Island. Besides gross morphological characters, features from the anatomy of berries, seeds, and leaf auricles (see Huynh, 2000: 283-284) are used as well. They have proved useful especially for distinguishing between closely related species (Huynh, 1997, 1999, 2000).

Since a large number of characters is now known for Freycinetia species, it appears useful to consider their use in identifying plants from New Guinea and looking for close relationships between species. The following characters would be of prime importance: the surface of stem internodes (generally smooth, granular in some species); the infructescences (generally terminal, but lateral in a small percentage of species); the numbers of stigmas (1-3, generally 2, sect. Oligostigma Warb.; 3-10 or more, sect. Pleiostigma Warb.: Warburg, 1900); the length and width of leaves, character generally used in the first step of species identification; the leaf shape; the number of spikes in infructescences (generally one or three); the presence or absence of a central sclerenchyma in berry pilei (Huynh, 1995: f. 2, 21), of fusiform/elliptic fibre bundles at successive levels along pilei in young berries and also along ovary walls in mature berries (Huynh, 1995: f. 1,4), of long fibre strands extending in a single stretch along berries, of crystal cells in seeds (Huynh, 1996: 533, f. 1, and 541, f. 19), of a ring around the stigmatic areola of berries; the seed shape (straight or sublunate, rarely strongly curved or spiral as shown in Huynh, 1996: f. 14, 18); gross morphological 
characters of leaf auricles (length; adnate or free at the apex); anatomical characters of leaf auricles (epidermis and hypodermis lignified or unlignified; fibre strands present or absent, separate or contiguous and forming a single band across the auricle width, long or short, viz. extending in a single stretch along auricle or distributed at successive levels: the anatomy of leaf auricles determines how these finally separate from leaves, for example by disintegrating longitudinally into separate fibres or breaking transversely into pieces, two processes frequently observed in the genus).

The following characters would be of secondary importance: presence or absence of a distinct strophiole in seeds (in those seeds where a distinct strophiole is observed, the part of the inner layer of the outer integument that is furthest away from the raphe is strongly developed and lignified: Huynh, 1996: 533, f. 1; 1997: 363, f. 4); the leaf blade when dry (patent, revolute, involute); the surface (scabrid or smooth) and length of syncarp peduncles; the armature of leaf margins and midrib; the syncarp length at maturity; the seed length; the length of infructescence peduncle; the length of stem internodes.

Further, the following characters may be used: the texture of leaves in dry state (chartaceous, membranaceous, submembranaceous, subcoriaceous, coriaceous); the distinctness or indistinctness of longitudinal veins and transverse veins in leaves when dry; the colour of leaves in dry state (greenish, dark greenish, brown/brownish, dark brown; it appears that this colour does not depend on how long ago leaves have been collected: for example, the leaves of all the specimens of $F$. funicularis collected in 2000 were dark brown when they were studied in the same year, while those of $F$. formosula collected in 1973 remain greenish); the colour of leaf auricles when dry; the margin of leaf auricles (armed or not).

Other characters may be added to these lists. The use of a large number of characters may give more accurate identifications, but makes it difficult to assess close relationships between species because it is not simple to decide which characters to use in the first place.

\section{DESCRIPTION OF SPECIES}

\section{Freycinetia admiraltiensis Huynh, spec. nov. (sect. Pleiostigma) - Fig. 1}

Internodia ramorum $1.5-3 \mathrm{~cm}$ longa, $1.5 \mathrm{~cm}$ crassa, laevia, teretia. Folia $20-22 \mathrm{~cm}$ longa, $2.2-2.8 \mathrm{~cm}$ lata in medio vel $1 / 4-1 / 3$ supera $1-1.2 \mathrm{~cm}$ in basi (auriculis non inclusis), lanceolata, abrupte attenuata infra apicem cum acumine $1 \mathrm{~cm}$ longo, raro sensim attenuata in $1 / 3$ supera cum cauda $2 \mathrm{~cm}$ longa, imbricata amplexicaulia in ramulis; in sicco \pm coriacea, atrobrunnea, patentia sed leviter revoluta in marginibus; costa media marginibusque inermibus, raro armatis (i.e. in aliquot foliis inferis, $8-12 \mathrm{~cm}$ longis, haud typicis, minute armatis in brevissimo spatio in apice); auriculis $5 \mathrm{~cm}$ longis, $5 \mathrm{~mm}$ latis. Infructescentia lateralis, 3 spicis praedita, axe $1.5 \mathrm{~cm}$ longo suffulta, prophyllis in basi praedito sed foliis destituto; syncarpiis $8 \mathrm{~cm}$ longis, $2.2 \mathrm{~cm}$ latis, submaturis, cylindricis, baccis in separatis gregibus, pedunculis $2.5 \mathrm{~cm}$ longis, $3.5 \mathrm{~mm}$ latis, sparsim scabridis. Baccae $9 \mathrm{~mm}$ longis, sclerenchymate-centrali in pileo et fasciculis fibrarum fusiformibus/ ellipticis praeditae; stigmatibus 4-5(-8), areola stigmatica annulo angusto sed distincto cincta. Semina $2 \mathrm{~mm}$ longa, $0.5 \mathrm{~mm}$ lata in medio, recta; strophiolo indistincto; endospermio $0.35 \mathrm{~mm}$ lato; raphe $0.08 \mathrm{~mm}$ lata. - Typus: Stone \& Streimann $10370=L A E$ 53670 (holo LAE), Bismarck Archipelago, Manus Is., Mt Dremsel, alt. 1800 ft, 21 June 1971. 


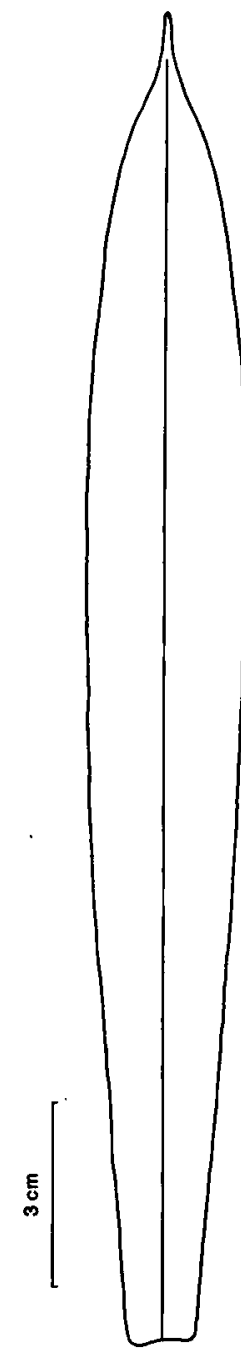

Fig. 1. Freycinetia admiraltiensis Huynh. Leaf flattened horizontally, viewed at the adaxial surface (auricles not shown) (Stone \& Streimann 10370).
Internodes of branches $1.5-3 \mathrm{~cm}$ long, $1.5 \mathrm{~cm}$ thick, smooth, terete. Leaves lanceolate, imbricate, $20-22$ by $2.2-2.8 \mathrm{~cm}$ at the middle or upper third to upper quarter, $1-1.2 \mathrm{~cm}$ at the base (auricles not included), abruptly attenuate below the apex with an acumen $1 \mathrm{~cm}$ long, rarely gradually attenuate in the upper third with a cauda $2 \mathrm{~cm}$ long, amplexicaul, in dry state \pm coriaceous, dark brown, patent but margins slightly revolute; longitudinal veins perspicuous on the abaxial surface, visible on the adaxial surface; transverse veins invisible; margins and midrib both unarmed (in some lower leaves, which are not typical because of being only $8-12 \mathrm{~cm}$ long, the margins and midrib are armed in a very short course at the apex); auricles partially preserved in some upper leaves, $5 \mathrm{~cm}$ by $5 \mathrm{~mm}$, membranaceous, dark brown, dull, nerved, densely and finely fibrous, (in the microscope) epidermis unlignified at both sides, mesophyll with vascular bundles and several long and separate fibre strands, blade slightly compressed between the fibre strands. Infructescence lateral, 3-spiked, the axis $1.5 \mathrm{~cm}$ long and with prophylls at the base but without leaves; syncarps cylindric, 8 by $2.2 \mathrm{~cm}$, almost mature, with berries in separate groups; peduncles $2.5 \mathrm{~cm}$ by $3.5 \mathrm{~mm}$, sparsely scabrid. Berries $9 \mathrm{~mm}$ long, with fusiform/elliptic fibre bundles and with a central sclerenchyma in the pileus; stigmas 4-5(-8), the stigmatic areola with a narrow but distinct and shining ring. Seeds straight, $2 \mathrm{~mm}$ long, $0.5 \mathrm{~mm}$ wide in the middle; strophiole indistinct; endosperm $0.35 \mathrm{~mm}$ wide; raphe $0.08 \mathrm{~mm}$ wide, with raphide cells but without crystal cells.

Field notes - Hill forest near summit. Climber to 15$18 \mathrm{ft}$ high, leaves green, inflorescences lateral, fruit dull glaucous green.

Notes - 1. The anatomy of the leaf auricles of $F$ admiraltiensis described above (epidermal cells all unlignified; mesophyll with several long and separate fibre strands) suggests that they probably disintegrated into separate fibres. Freycinetia admiraltiensis is noteworthy in that its berries form separate groups on the syncarps; its leaves are entirely unarmed, at least those which are typical to this species; its seeds are among the longest in the genus, up to $2 \mathrm{~mm}$.

2. Apparently there are no species very closely related to $F$. admiraltiensis. This species shows some resemblance with $F$. madangensis (Papua New Guinea) and $F$, normanbyensis (Normanby Is.), both of which also have lateral infructescences. Freycinetia normanbyensis also belongs to sect. Pleiostigma, but its stem is granular, and its seeds are $1.2 \mathrm{~mm}$ long and have a distinct strophiole. Freycinetia madangensis 
belongs to sect. Oligostigma, its berries do not have a ring around the stigmatic areola, and its seeds are $1 \mathrm{~mm}$ long and have a distinct strophiole (Huynh, 2000: 286). Further, $F$. admiraltiensis also shows some resemblance with $F$. novobritannica (New Britain), which also has lateral infructescences. Freycinetia novobritannica belongs to sect. Oligostigma, its syncarps are $2.5 \mathrm{~cm}$ long when mature and have a smooth peduncle, its berries do not have a ring around the stigmatic areola, its seeds are $1.3 \mathrm{~mm}$ long and have a distinct strophiole, its leaves are chartaceous when dry and have only short fibre strands in the auricles; in particular, its leaf auricles roll up twice when dry, a feature not observed in any other known species of Freycinetia. Another difference: in $F$. madangensis, $F$. normanbyensis, and $F$. novobritannica, the berries do not form separate groups on the syncarps.

\title{
2. Freycinetia amoena Huynh, spec. nov. (sect. Oligostigma) - Fig. 2
}

\begin{abstract}
Ramulus fructifer internodiis $1 \mathrm{~cm}$ longis, $5 \mathrm{~mm}$ crassis, laevibus, teretibus compositus. Folia infra infructescentiam (14-) 17-20 cm longa, $2-3 \mathrm{~cm}$ lata in medio $8 \mathrm{~mm}$ in basi (auriculis non inclusis), lanceolata, 4-5 mm acuminata, dissita, in basi semiamplexicaulia; in sicco viridula sed abrupte atrobrunneissima in apice, membranacea/chartacea, patentia; marginibus armatis ex apice ad vaginam; costa media armata in dimidio supero circiter; auriculis $5 \mathrm{~cm}$ longis, $5 \mathrm{~mm}$ latis, in separatis fibris solutis. Infructescentia terminalis, 4 spicis praedita, pedunculo communi $1 \mathrm{~cm}$ longo; syncarpiis $3.5 \mathrm{~cm}$ longis, $1.5 \mathrm{~cm}$ latis, immaturis, cylindricis, pedunculis $3 \mathrm{~cm}$ longis, $2 \mathrm{~mm}$ latis, laevibus. Baccae sclerenchymate-centrali in pileo praeditae sed fibris destitutae; stigmatibus 2 , raro 3, arte aggregatis igitur plerumque indistinctis, areola stigmatica annulo destituta. - Typus: Stone \& Streimann 10473 = LAE 53773 (holo LAE), Bismarck Archipelago, Manus Is., Wili River between Pelikawa and Dremsel, alt. c. 500 ft, 26 June 1971.
\end{abstract}

Fruit-bearing branchlet partially preserved, the remnant $20 \mathrm{~cm}$ long; internodes $1 \mathrm{~cm}$ long, $5 \mathrm{~mm}$ thick, smooth, terete. Leaves below the infructescence lanceolate, remote, (14-)17-20 cm long, 2-3 cm wide at the middle, $8 \mathrm{~mm}$ at the base (auricles not included), 4-5 mm acuminate, semiamplexicaul at the base, in dry state greenish but abruptly very dark brown at the apex, membranaceous/chartaceous, striate on both surfaces, patent; longitudinal veins perspicuous on the abaxial surface, obscure on the adaxial surface; transverse veins invisible, sometimes visible on the abaxial surface; margins armed from the apex to the sheath, prickles dense and up to $1 / 2-2 / 3 \mathrm{~mm}$ long in the upper part, sparse and shorter, at most 1/5-1/4 mm long, in the lower part; midrib armed in the upper half, prickles \pm as long as those of the margins; auricles almost all preserved, $5 \mathrm{~cm}$ by $5 \mathrm{~mm}$, membranaceous, brown, dull, in separate fibres, (in the microscope) epidermis unlignified at both sides, mesophyll with vascular bundles and several long and separate fibre strands, blade slightly compressed between the fibre strands. Infructescence terminal, 4-spiked, peduncle $1 \mathrm{~cm}$ long; syncarps cylindric, 3.5 by $1.5 \mathrm{~cm}$, immature; peduncles $3 \mathrm{~cm}$ by $2 \mathrm{~mm}$, smooth. Berries with a central sclerenchyma in the pileus but without fibres; stigmas 2 , rarely 3 , closely aggregated hence mostly indistinct, the stigmatic areola having no ring.

Field notes - Lowland rain forest. Woody climber to 25-30 ft high.

Notes - 1. The anatomy of the leaf auricles of F. amoena described above (epidermal cells all unlignified; mesophyll with several long and separate fibre strands) accounts for their disintegration into separate fibres. Since the stigmas are mostly indistinct, their numbers on berries were determined by observing the numbers of 
fertilisation canals in the transverse sections of pilei, each fertilisation canal corresponding to one stigma (see Huynh, 2000: 284).

2. Freycinetia amoena is named in reference to the pleasant aspect of its leaves. These are most unusual in Freycinetia given that in dry state, their tip is very dark brown, contrasting strongly with the greenish blade. This indicates that when fresh, the former is different in colour from the latter; it is probably red or orange. Freycinetia amoena is also noteworthy in that the lower prickles of its leaf margins are distinctly shorter than the upper prickles, contrary to the general case.

3. Apparently there are no species very closely related to $F$. amoena. This species shows some resemblance with F. concolor, Papua New Guinea (Huynh, 2000: 287), and F. woodlarkensis, Woodlark Island. These two species differ from $F$. amoena in that they both belong to sect. Pleiostigma; in addition, their leaf tips when dry are of the same colour as the leaf blades, and their leaf auricles are half as long or less for \pm the same leaf length.

3. Freycinetia angusta Huynh, spec. nov. (sect. Oligostigma) - Fig. 3

Ramuli fructiferi internodiis 5-6 mm longis, $2.5 \mathrm{~mm}$ crassis, laevibus, teretibus compositi. Folia infra infructescentiam (5-)8-9 cm longa, 2.5-3(-4) mm lata in parte media $2.5-3$ $\mathrm{mm}$ in basi (auriculis non inclusis), lineari-sublanceolata, $5 \mathrm{~mm}$ acuminata, imbricata, in basi semiamplexicaulia; in sicco atrobrunnea, subcoriacea, patentia sed leviter revoluta in marginibus; marginibus armatis in dimidio supero, interdum in infero etiam; costa media armata in parte supera; auriculis $1.3 \mathrm{~cm}$ longis, $3 \mathrm{~mm}$ latis, in apice adnatis et subacutis, fere ad basim armatis. Infructescentia terminalis, monosyncarpica; syncarpio

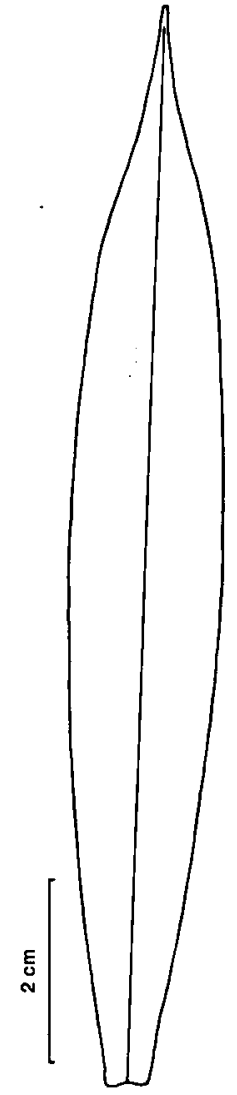

Fig. 2. Freycinetia amoena Huynh. Leaf flattened horizontally, viewed at the adaxial surface (auricles not shown) (Stone \& Streimann 10473). $2 \mathrm{~cm}$ longo, $1.5 \mathrm{~cm}$ lato, immaturo, ovoideo/subgloboso, pedunculo $1 \mathrm{~cm}$ longo, $2 \mathrm{~mm}$ lato, scabrido. Baccae sclerenchymate-centrali in pileo praeditae sed fibris destitutae; stigmatibus 2 , raro 3 vel 4, areola stigmatica annulo perspicuo cincta. - Typus: Brass 24795 (holo L; iso LAE), D'Entrecasteaux Is., Goodenough Is., east slopes, alt. $1600 \mathrm{~m}, 18$ October 1953.

Fruit-bearing branchlets $5-10 \mathrm{~cm}$ long in axis; internodes 5-6 mm long, $2.5 \mathrm{~mm}$ thick, smooth, terete. Leaves below the infructescence linear-sublanceolate, imbricate, (5-) 8-9 $\mathrm{cm}$ long, 2.5-3(-4) $\mathrm{mm}$ wide in the middle part, $2.5-3 \mathrm{~mm}$ at the base (auricles not included), $5 \mathrm{~mm}$ acuminate, semiamplexicaul at the base, in dry state dark brown, subcoriaceous, partially striate on the adaxial surface, not striate on the abaxial surface, patent but margins slightly revolute; longitudinal veins visible on both surfaces but transverse veins invisible; margins armed in the upper half, sometimes also in the lower half, prickles up to $1 / 3 \mathrm{~mm}$ long; midrib armed in the upper part; auricles preserved in some upper leaves, $1.3 \mathrm{~cm}$ by $3 \mathrm{~mm}$, adnate and subacute at the apex, membra- 


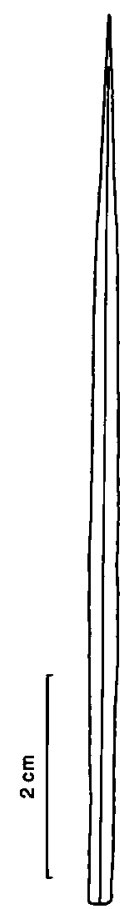

Fig. 3. Freycinetia angusta Huynh. Leaf flattened horizontally, viewed at the adaxial surface (auricles not shown) (Brass 24795).

Perry, 1939: 141; Huynh, 1999: f. 8). A peculiar feature of $F$. polyclada that is not observed in $F$. angusta is that the uppermost lateral branchlets are numerous and very closely arranged on the branch axes, being separated from one another by only 4-5 mm or less; as a consequence, they appear as forming a very dense tuft of leaves (Huynh, 1999: 182, f. 13).

\section{Freycinetia awaiarensis Huynh, spec. nov. (sect. Pleiostigma) - Fig. 4}

Internodia in ramulis fructiferis ramisque 3-5(-7) $\mathrm{mm}$ longa, 3-3.5 mm crassa, laevia, trigona. Folia infra infructescentiam $5-5.5 \mathrm{~cm}$ longa, 0.9-1.1 cm lata in medio $5-6 \mathrm{~mm}$ in basi (auriculis non inclusis), lanceolata, 1-3 mm acuminata, dissita, in basi semiamplexicaulia; in sicco brunnea/brunneola, subcoriacea, patentia, interdum leviter revoluta in marginibus; marginibus inermibus, interdum armatis in brevissimo spatio in apice; costa media inermi, raro armata in brevissimo spatio in apice; auriculis $1.5 \mathrm{~cm}$ longis, $3 \mathrm{~mm}$ latis, triangularibus, in apice adnatis, inermibus vel armatis in apice. Infructescentia terminalis, 3 spicis praedita, pedunculo communi $5 \mathrm{~mm}$ longo; syncarpiis $2 \mathrm{~cm}$ longis, $1.5-1.7 \mathrm{~cm}$ latis, immaturis, ellipticis, pedunculis $1 \mathrm{~cm}$ longis, $2 \mathrm{~mm}$ latis, laevibus. Baccae sclerenchymate-centrali fibrisque destitutae; stigmatibus (2-)3-5, areola stigmatica annulo destituta. - Typus: Brass 25791 (holo LAE), D'Entrecasteaux Is., Normanby Is., Mt Pabinama, alt. 950 m, 9 May 1956. 


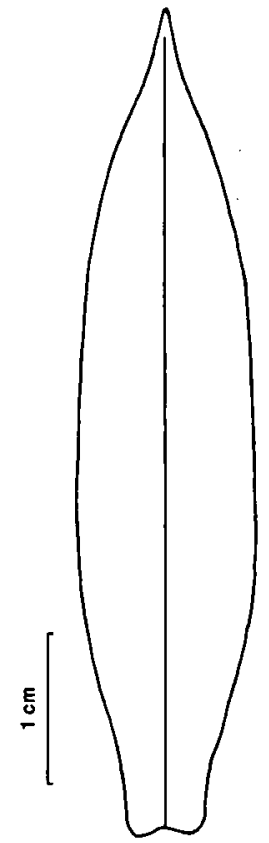

Fig. 4. Freycinetia awaiarensis Huynh. Leaf flattened horizontally, viewed at the adaxial surface (auricles not shown) (Brass 25791).
Fruit-bearing branchlets $16-17 \mathrm{~cm}$ long. Internodes in both branches and fruit-bearing branchlets trigonous, 3-5(-7) mm long, 3-3.5 mm thick, smooth. Leaves below the infructescence lanceolate, remote, $5-5.5 \mathrm{~cm}$ long, $0.9-1.1$ $\mathrm{cm}$ wide at the middle, 5-6 $\mathrm{mm}$ at the base (auricles not included), lanceolate, 1-3 mm acuminate, remote, semiamplexicaul at the base, in dry state brown/brownish, subcoriaceous, striate on both surfaces, patent, sometimes margins revolute; longitudinal veins distinct on the abaxial surface, less so on the adaxial surface; transverse veins invisible; margins unarmed, sometimes armed at the apex with minute prickles, sometimes up to $1 / 3 \mathrm{~mm}$ long; midrib unarmed, rarely armed at the apex; auricles preserved in some upper leaves, triangular, $1.5 \mathrm{~cm}$ by $3 \mathrm{~mm}$, adnate at the apex, unarmed or armed at the apex, membranaceous, brown, dull, nerved, fibrous, (in the microscope) epidermis unlignified at both sides, mesophyll with vascular bundles and long and separate fibre strands, blade strongly compressed between the fibre strands. Infructescence terminal, 3-spiked, peduncle $5 \mathrm{~mm}$ long; syncarps elliptic, 2 by $1.5-1.7 \mathrm{~cm}$, immature, peduncles $1 \mathrm{~cm}$ by $2 \mathrm{~mm}$, smooth. Berries without a central sclerenchyma and without fibres; stigmas (2-)3-5, the stigmatic areola having no ring.

Field note - Scrubby mossy forest of summit.

Notes - 1. Freycinetia awaiarensis and F. normanbyensis described below seem to be the first species of Freycinetia observed in Normanby Island. Freycinetia awaiarensis is named after Awaiara Bay, the largest bay that borders Normanby Island.

2. The anatomy of the leaf auricles of $F$. awaiarensis described above (epidermal cells all unlignified; mesophyll with several long and separate fibre strands) suggests that they probably disintegrated into separate fibres.

3. Freycinetia awaiarensis is noteworthy in that the internodes of its fertile branchlets and the branches bearing these are exceptionally short, 3-5(-7) mm long; its leaves are generally unarmed.

4. Apparently there are no species very closely related to $F$. awaiarensis. This species shows some resemblance with $F$. flaviceps (Irian Jaya). This latter species differs from $F$. awaiarensis especially in its berries which have two stigmas and therefore belongs to sect. Oligostigma, its syncarp peduncles which are hispidulous, and in its fertile branchlet internodes which are up to $1.5 \mathrm{~cm}$ long (Huynh, 2000: 295-296).

\section{Freycinetia boluboluensis Huynh, spec. nov. (sect. Pleiostigma) - Fig. 5}

Ramuli fructiferi internodiis brevibus, laevibus, teretibus compositi. Folia infra infructescentiam 10-12 cm longa, (4-)5-7 mm lata in parte media $4 \mathrm{~mm}$ in basi (auriculis non inclusis), subensiformia, acuta et 1-2 mm acuminata, imbricata, in basi amplexicaulia; 
in sicco brunnea, submembranacea/subcoriacea, patentia sed leviter revoluta in marginibus; marginibus armatis in brevi spatio in apice solum, raro supra basim etiam; costa media armata in dimidio supero circiter; auriculis $2 \mathrm{~cm}$ longis, $4 \mathrm{~mm}$ latis, in apice adnatis, fere ad basim armatis. Infructescentia terminalis, monosyncarpica; syncarpio $4.5 \mathrm{~cm}$ longo, $3 \mathrm{~cm}$ lato, maturo, elliptico, pedunculo $9 \mathrm{~mm}$ longo, $3 \mathrm{~mm}$ lato, scabrido. Baccae 6-7 mm longae, sclerenchymate-centrali in pileo praeditae sed fibris destitutae; stigmatibus generaliter 3 vel 4, areola stigmatica annulo destituta; pileo $3 \mathrm{~mm}$ longo, pyramidali. Semina $1.6 \mathrm{~mm}$ longa, $0.6 \mathrm{~mm}$ lata in medio, recta; strophiolo distincto, $0.15 \mathrm{~mm}$ lato; endospermio $0.3 \mathrm{~mm}$ lato; raphe distincta, $0.15 \mathrm{~mm}$ lata. - Typus: Benjamin LAE 67924 (holo L), D'Entrecasteaux Is., Goodenough Is., subprovince Bolubolu, Mt Oiatawa'a, alt. $1400 \mathrm{~m}, 21$ December 1977.

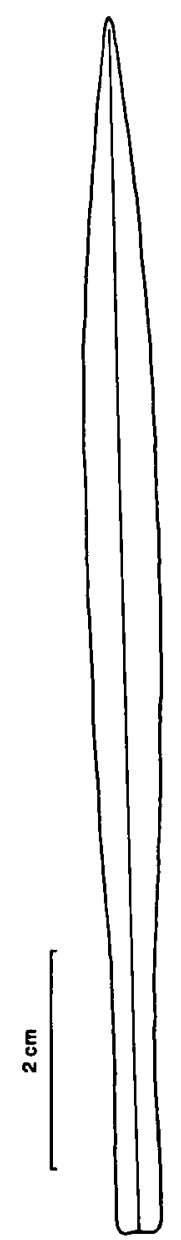

Fig. 5. Freycinetia boluboluensis Huynh. Leaf flattened horizontally, viewed at the adaxial surface (auricles not shown) (Beniamin LAE 67924).
Fruit-bearing branchlets $6-7 \mathrm{~cm}$ long in axis; internodes short, smooth, terete. Leaves below the infructescence subensiform, imbricate, $10-12 \mathrm{~cm}$ long, (4-)5-7 $\mathrm{mm}$ wide in the middle part, $4 \mathrm{~mm}$ at the base (auricles not included), acute and 1-2 $\mathrm{mm}$ acuminate, amplexicaul at the base, in dry state brown, submembranaceous or subcoriaceous, striate on both surfaces, patent but margins slightly revolute; longitudinal veins perspicuous on the abaxial surface, \pm visible on the adaxial surface; transverse veins invisible; margins armed in a short course at the apex only, rarely also above the base, prickles up to $2 / 5 \mathrm{~mm}$ long; midrib armed in the upper half, prickles up to $2 / 3 \mathrm{~mm}$ long; auricles preserved in some upper leaves, $2 \mathrm{~cm}$ by $4 \mathrm{~mm}$, adnate at the apex, membranaceous, brownish, dull, armed almost to the base, striate, 2- or 3-nerved, (in the microscope) epidermis not or slightly lignified, mesophyll with long and 1-3-layered fibre strands which are contiguous and form a single band over 2 or 3 vascular bundles, blade not compressed. Infructescence terminal, monosyncarpic; syncarp elliptic, 4.5 by $3 \mathrm{~cm}$, mature, peduncle 9 by $3 \mathrm{~mm}$, scabrid. Berries 6-7 mm long, with a central sclerenchyma in the pileus but without fibres; stigmas generally 3 or 4 , the stigmatic areola without ring; pileus $3 \mathrm{~mm}$ long, pyramidal. Seeds $1.6 \mathrm{~mm}$ long, $0.6 \mathrm{~mm}$ wide in the middle, straight; strophiole distinct, $0.15 \mathrm{~mm}$ wide; endosperm $0.3 \mathrm{~mm}$ wide; raphe distinct, $0.15 \mathrm{~mm}$ wide, with raphide cells but without crystal cells.

Field notes - Undisturbed primary (mossy) forest. Leaves dark green above, paler below.

Notes - 1. Freycinetia boluboluensis is noteworthy by its leaf auricles, whose fibre strands in the mesophyll form a single band across the auricle width. This anatomy suggests that the auricles did not disintegrate into separate fibres.

2. Apparently there are no species very closely related to $F$. boluboluensis. This species shows some resemblance to F. misimica (Louisiade Archipelago). This latter species differs from $F$. boluboluensis especially in its infructescence which 
has three spikes, and in its leaves which are different in shape (Huynh, 1999: f. 25); in particular, the fibre strands in the mesophyll of its leaf auricles do not form a single band across the auricle width, but instead, are separate from one another (Huynh, 1999: 170).

\section{Freycinetia fergussonensis Huynh, spec. nov. (sect. Pleiostigma) - Fig. 6}

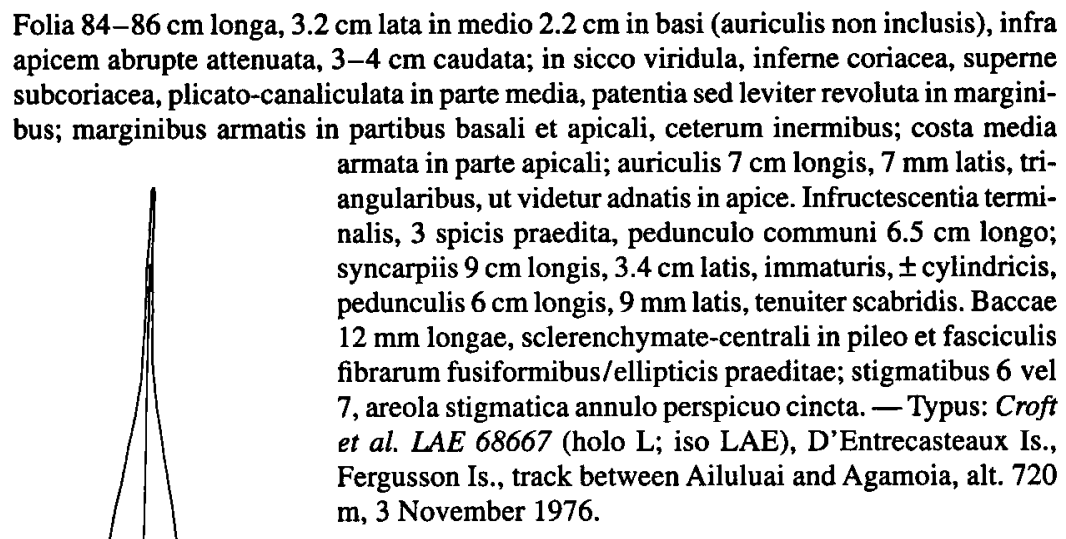

Leaves $84-86 \mathrm{~cm}$ long, $3.2 \mathrm{~cm}$ wide at the middle, 2.2 $\mathrm{cm}$ at the base (auricles not included), abruptly attenuate below the apex, 3-4 cm caudate, in dry state greenish, coriaceous below, subcoriaceous above, striate on both surfaces, plicate and canaliculate in the middle part, patent but margins slightly revolute; longitudinal veins visible on both surfaces but transverse veins partly so; margins armed in the basal part with prickles up to $1.5 \mathrm{~mm}$ long, in the apical part with prickles hardly $1 / 4 \mathrm{~mm}$ long, unarmed between; midrib armed in the apical part, prickles up to $1 \mathrm{~mm}$ long; auricles $7 \mathrm{~cm}$ by $7 \mathrm{~mm}$, triangular, apparently adnate at the apex, membranaceous, brown. Infructescence terminal, 3-spiked, peduncle $6.5 \mathrm{~cm}$ long; syncarps \pm cylindric, 9 by $3.4 \mathrm{~cm}$, immature, peduncles $6 \mathrm{~cm}$ by $9 \mathrm{~mm}$, finely scabrid. Berries $12 \mathrm{~mm}$ long, with fusiform or elliptic fibre bundles and with a central sclerenchyma in the pileus; stigmas 6 or 7, the stigmatic areola with a perspicuous and shining ring.

Field notes - Hill forest. Leaves semigloss, dark green above, mid green below, inflorescence a cluster of 3 terminal heads, fruit red.

Notes - 1. Freycinetia fergussonensis and F. lenifolia

Fig. 6. Freycinetia fergussonensis Huynh. Upper part of leaf flattened horizontally, viewed at the adaxial surface (Croft et al. LAE 68667). described below seem to be the first species of Freycinetia observed in Fergusson Island.

2. Freycinetia fergussonensis appears closest to $F$. percostata (Papua New Guinea). This latter species differs 
from $F$. fergussonensis especially in its berries which have 8-12 stigmas, and in its syncarps which are $13.5 \mathrm{~cm}$ long when young and $21 \mathrm{~cm}$ when mature, a length which apparently cannot be reached by the syncarps of $F$. fergussonensis at maturity; in particular, its leaves are gradually attenuate in the apical part (Merrill \& Perry, 1939: 159).

7. Freycinetia formosula Huynh, spec. nov. (sect. Pleiostigma) - Fig. 7

\begin{abstract}
Folia infra infructescentiam (14-)55-60 cm longa, $1.2 \mathrm{~cm}$ lata in medio $1 \mathrm{~cm}$ prope basim $1.2 \mathrm{~cm}$ in basi (auriculis non inclusis), lineari-ensiformia, $2-3 \mathrm{~cm}$ caudata, imbricata, in basi amplexicaulia; in sicco viridula, submembranacea/subcoriacea, patentia sed saepe leviter involuta in marginibus in parte media; marginibus armatis ex apice ad vaginam; costa media armata in $1 / 3$ supera circiter; auriculis $4-5 \mathrm{~cm}$ longis, $5-6 \mathrm{~mm}$ latis, in apice adnatis et oblique truncatis, armatis in apice. Infructescentia terminalis, 3 spicis praedita, pedunculo communi $4 \mathrm{~cm}$ longo; syncarpiis $4 \mathrm{~cm}$ longis, $1 \mathrm{~cm}$ latis, immaturis, $\mathrm{cy}$ lindricis, pedunculis $2 \mathrm{~cm}$ longis, $4 \mathrm{~mm}$ latis, dense scabridis. Baccae sclerenchymate-centrali in pileo praeditae sed fibris destitutae; stigmatibus 3-4(-6), perspicuissimis, areola stigmatica annulo distincto cincta. - Typus: Foreman LAE 52355 (holo LAE), Bismarck Archipelago, Manus Is., Derimbat, alt. $200 \mathrm{~m}, 28$ June 1973.
\end{abstract}

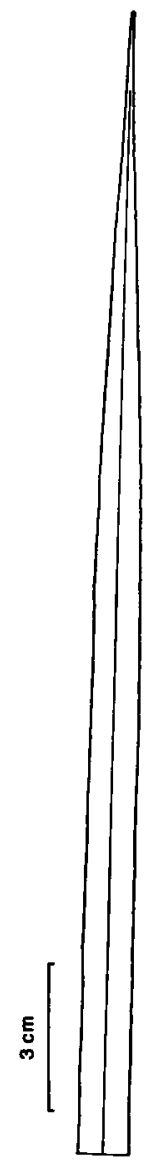

Fig. 7. Freycinetia formosula Huynh. Upper part of leaf flattened horizontally, viewed at the adaxial surface (Foreman LAE 52355).

Leaves below the infructescence linear-ensiform, imbricate, (14-) $55-60 \mathrm{~cm}$ long, $1.2 \mathrm{~cm}$ wide at the middle, $1 \mathrm{~cm}$ near the base, $1.2 \mathrm{~cm}$ at the base (auricles not included), 2-3 $\mathrm{cm}$ caudate, amplexicaul at the base, in dry state greenish, submembranaceous or subcoriaceous, striate on the adaxial surface, not striate but tessellate on the abaxial surface, patent but margins frequently slightly involute in the middle part; longitudinal veins and transverse veins visible on the abaxial surface, invisible on the adaxial surface; margins armed from the apex to the sheath, prickles up to $1 \mathrm{~mm}$ long in the lower part, minute in the upper part; midrib armed in the upper third, prickles minute, very sparse below; auricles all preserved, $4-5 \mathrm{~cm}$ by $5-6 \mathrm{~mm}$, adnate and obliquely truncate at the apex, armed at the apex with prickles up to $2 / 3 \mathrm{~mm}$ long, \pm membranaceous, brown, dull, slightly nerved, smooth, (in the microscope) epidermis almost entirely lignified at both sides, hypodermis with one lignified layer at one side but 2 or 3 lignified layers at the other side, mesophyll with vascular bundles and several long and separate fibre strands, blade not compressed between the fibre strands. Infructescence terminal, 3-spiked, peduncle $4 \mathrm{~cm}$ long; syncarps cylindric, 4 by $1 \mathrm{~cm}$, immature; peduncles $2 \mathrm{~cm}$ by $4 \mathrm{~mm}$, densely scabrid. Berries with a central sclerenchyma in the pileus but without fibres; stigmas 3-4(-6), very distinct, the stigmatic areola with a distinct and shining ring. 
Field notes - Ridge forest. Climber on small tree, leaves dark green, flower bracts reddish orange, young fruit green.

Notes - 1. Freycinetia formosula is named in reference to the pretty aspect of the plant, the leaf auricles, and the stigmas. It is remarkable by its leaf auricles whose hypodermis is entirely and strongly lignified, with one cell layer at one side and 2 or 3 cell layers at the other side. With such a hypodermis, which was seldom observed in $F r e y c i n e t i a$, the leaf auricles of $F$. formosula will probably not disintegrate into separate fibres.

2. Freycinetia formosula is very close to $F$. manusensis. This latter species differs from $F$. formosula especially in its leaves. These are shorter but wider $(45$ by $1.5 \mathrm{~cm})$; the margins are unarmed in the middle part and involute almost from the base to the apex; in particular, the hypodermis of the auricles is lignified at one side only and with only one cell layer (Huynh, 1999: 166-167). Freycinetia formosula also appears distinct from $F$. manusensis in the shape of the apical part of its leaves. Furthermore, in living state, the bracts of $F$. formosula are reddish orange as field-noted above, while those of $F$. manusensis were field-noted as being red (Huynh, 1999: 167). This difference also suggests that the former species is distinct from the latter.

\section{Freycinetia goodenoughensis Huynh, spec. nov. (sect. Pleiostigma) - Fig. 8}

\begin{abstract}
Ramuli fructiferi internodiis $5-10 \mathrm{~mm}$ longis, $2.5 \mathrm{~mm}$ crassis, laevibus, teretibus compositi. Folia infra infructescentiam 8-10 cm longa, 4-5 mm lata in parte media $2 \mathrm{~mm}$ in basi (auriculis non inclusis), anguste lanceolata sed plerumque leviter curvata, acuta et $1 \mathrm{~mm}$ acuminata, dissita, in basi semiamplexicaulia; in sicco brunnea/brunneola, submembranacea sed leviter rigida, patentia; marginibus perminute armatis in $1 \mathrm{~cm}$ in apice solum, interdum inermibus; costa media minute et sparsim armata in dimidio supero circiter; auriculis $1.5 \mathrm{~cm}$ longis, $3 \mathrm{~mm}$ latis, triangularibus, in apice adnatis, ut videtur minute armatis in apice, in separatis fibris solutis. Infructescentia terminalis, ( 2 vel) 3 spicis praedita, pedunculo communi 6-7 mm longo; syncarpiis $1.3 \mathrm{~cm}$ longis, $0.9 \mathrm{~cm}$ latis, immaturis, breviter ellipticis, pedunculis $1.1 \mathrm{~cm}$ longis, $2 \mathrm{~mm}$ latis, laevibus. Baccae sclerenchymate-centrali in pileo praeditae sed fibris destitutae; stigmatibus 3 vel 4, interdum 5 vel 6, omnibus annulo separato cinctis. - Typus: Brass 24559 (holo L; iso LAE), D'Entrecasteaux Is., Goodenough Is., east slopes, alt. $1750 \mathrm{~m}, 15-21$ October 1953.
\end{abstract}

Fruit-bearing branchlets partially preserved, the remnant 30 cm long; internodes 5-10 $\mathrm{mm}$ long, $2.5 \mathrm{~mm}$ thick, smooth, terete. Leaves below the infructescence narrowly lanceolate, mostly slightly curved, remote, $8-10 \mathrm{~cm}$ long, $4-5 \mathrm{~mm}$ wide in the middle part, $2 \mathrm{~mm}$ at the base (auricles not included), acute and $1 \mathrm{~mm}$ acuminate, semiamplexicaul at the base, in dry state brown/brownish, submembranaceous but slightly rigid, striate on the adaxial surface, patent; longitudinal veins visible on the abaxial surface, mostly invisible on the adaxial

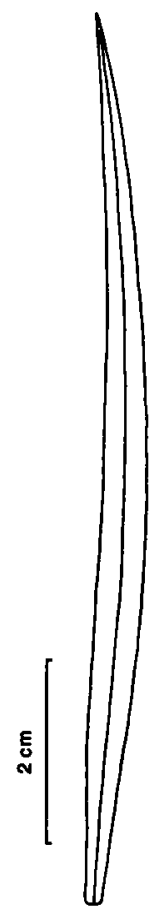

Fig. 8. Freycinetia goodenoughensis Huynh. Leaf flattened horizontally and viewed at the adaxial surface (auricles not shown) (Brass 24559). 
surface; transverse veins invisible; margins very minutely armed along $1 \mathrm{~cm}$ at the apex only, sometimes unarmed; midrib minutely and sparsely armed in the upper half; auricles partially preserved in some upper leaves, triangular, $1.5 \mathrm{~cm}$ by $3 \mathrm{~mm}$, adnate at the apex, scarious, brownish, dull, fibrous, apparently armed at the apex, disintegrating into separate fibres, (in the microscope) epidermis unlignified at both sides, mesophyll with several long and separate fibre strands but apparently without vascular bundles, blade perspicuously compressed between the fibre strands. Infructescence terminal, (2- or) 3-spiked, peduncle 6-7 mm long; syncarps shortelliptic, 1.3 by $0.9 \mathrm{~cm}$, immature, peduncles $1.1 \mathrm{~cm}$ by $2 \mathrm{~mm}$, smooth. Berries with a central sclerenchyma in the pileus but without fibres; stigmas 3 or 4 , sometimes 5 or 6 , each with a separate shining ring.

Field notes - Plentiful in low heavily mossed forest of ridge crests. Much branched, climbing to $6-8 \mathrm{~m}$.

Notes -1 . The anatomy of the leaf auricles of $F$. goodenoughensis described above (epidermal cells all unlignified; mesophyll with several long and separate fibre strands) accounts for their disintegration into separate fibres.

2. Freycinetia goodenoughensis is most unusual considering its stigmas which are each surrounded completely or almost completely by a distinct ring, a very rare feature in Freycinetia. It appears closest to $F$. dissita (Papua New Guinea). This latter species differs from $F$. goodenoughensis in its syncarp peduncles which are scabrid, and in particular, in its leaves which are strongly revolute (Huynh, 1999: 167, 169).

\title{
9. Freycinetia granulata Huynh, spec. nov. (sect. Pleiostigma) - Fig. 9
}

\begin{abstract}
Ramulus fructifer internodiis $5-8 \mathrm{~mm}$ longis, $3.5 \mathrm{~mm}$ crassis, tenuiter granularibus, trigonis compositus. Folia infra infructescentiam $14-16 \mathrm{~cm}$ longa, $1.5-1.7 \mathrm{~cm}$ lata in medio $5 \mathrm{~mm}$ in basi (auriculis non inclusis), lanceolata, 1-2 $\mathrm{mm}$ acuminata, dissita, in basi amplexicaulia; in sicco \pm atrobrunnea, chartacea/membranacea, patentia; marginibus armatis in brevissimo spatio in apice, raro cum 1 vel 2 denticulis prope basim etiam; costa media armata in parte apicali, in spatio longiore quam marginibus; auriculis ut videtur $2 \mathrm{~cm}$ longis $5 \mathrm{~mm}$ latis, fere ad basim armatis, in separatis fibris solutis. Infructescentia terminalis, 4 spicis praedita, pedunculo communi $5 \mathrm{~mm}$ longo; syncarpiis $2.3 \mathrm{~cm}$ longis, $2.3 \mathrm{~cm}$ latis, maturis, subglobosis, pedunculis $1.5 \mathrm{~cm}$ longis, $3.5 \mathrm{~mm}$ latis, laevibus. Baccae sclerenchymate-centrali in pileo praeditae sed fibris destitutae; stigmatibus 3-5, areola stigmatica annulo angusto sed distincto cincta. Semina $1.1 \mathrm{~mm}$ longa, $0.5 \mathrm{~mm}$ lata in medio, recta; endospermio ca. 1/2 latitudinis seminis lato; strophiolo distincto, paululo latiore quam raphe. - Typus: Frodin NGF 26545 (holo L), Bismarck Archipelago, New Britain, 5 miles north of old site of Omoi (Arawe area), east bank of river, alt. $5 \mathrm{ft}, 2$ April 1966.
\end{abstract}

Fruit-bearing branchlet partially preserved, the remnant $20 \mathrm{~cm}$ long; internodes trigonous, 5-8 mm long, $3.5 \mathrm{~mm}$ thick, finely granular (in the specimen, the granules are distinct on the sterile branchlet but hardly visible on the fruit-bearing branchlet). Leaves below the infructescence lanceolate, remote, $14-16 \mathrm{~cm}$ long, $1.5-1.7 \mathrm{~cm}$ wide at the middle, $5 \mathrm{~mm}$ at the base (auricles not included), 1-2 mm acuminate, amplexicaul at the base, in dry state \pm dark brown, chartaceous or membranaceous, striate on the adaxial surface, patent; longitudinal veins perspicuous on the abaxial surface, hardly visible on the adaxial surface; transverse veins partially visible on the abaxial surface; margins armed in a very short course at the apex, rarely with 1 or 2 prickles near the 
base, these up to $1 / 2 \mathrm{~mm}$ long; midrib armed in the apical part along a longer course than on the margins, prickles sparse and up to $1 / 2 \mathrm{~mm}$ long; auricles partially preserved in some leaves, apparently $2 \mathrm{~cm}$ by $5 \mathrm{~mm}$, armed almost to the base, membranaceous, dark brown, dull, densely fibrous, in separate fibres, (in the microscope) epidermis unlignified at both sides, mesophyll with 2 or 3 vascular bundles and long, remote and 2-4-layered fibre strands, blade not compressed between the fibre strands. Infructescence terminal, 4-spiked, peduncle $5 \mathrm{~mm}$ long; syncarps subglobose, 2.3 by $2.3 \mathrm{~cm}$, mature, peduncles 1.5 cm by $3.5 \mathrm{~mm}$, smooth. Berries with a central sclerenchyma in the pileus but without fibres; stigmas 3-5, the stigmatic areola with a narrow but distinct and shining ring. Seeds straight, $1.1 \mathrm{~mm}$ long, $0.5 \mathrm{~mm}$ wide in the middle; endosperm about half the seed width; strophiole distinct, a little wider than the raphe; raphe with raphide cells present but without crystal cells.

Field notes - Sago swamp forest. Leaves green on both sides, fruit red.

Notes - 1. The anatomy of the leaf auricles of $F$. granulata described above (epidermal cells all unlignified; mesophyll with several long and separate fibre strands) accounts for their disintegration into separate fibres.

2. Freycinetia granulata appears closest to F. takeuchii (Papua New Guinea), considering in particular their granular stems. Freycinetia takeuchii differs from F. granulata especially in its seeds which do not have a distinct strophiole, its stem internodes which are longer (up to $1.5 \mathrm{~cm}$ ), and in its leaf midrib which is armed from the apex almost to the base; in particular, its leaf auricles do not have separate fibre strands, and therefore they do not disintegrate into separate fibres but break into fragments (Huynh, 2000: 289).

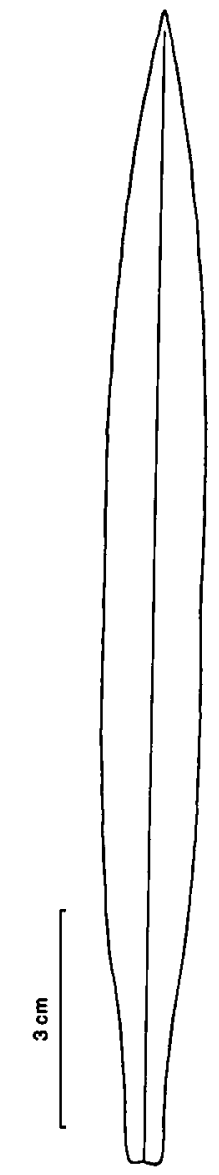

Fig. 9. Freycinetia granulata Huynh. Leaf flattened horizontally, viewed at the adaxial surface (auricles not shown) (Frodin NGF 26545).

10. Freycinetia lanceolata Huynh, spec. nov. (sect. Oligostigma) - Fig. 10

Ramuli fructiferi internodiis 3-9 mm longis, 3-4 mm crassis, laevibus, teretibus compositi. Folia infra infructescentiam $5-9 \mathrm{~cm}$ longa, $0.7-1.3 \mathrm{~cm}$ lata in parte media $0.5 \mathrm{~cm}$ in basi (auriculis non inclusis), lanceolata, 4-5 mm acuminata, dissita, in basi semiamplexicaulia; in sicco brunnea, membranacea; marginibus armatis ex apice fere ad vaginam; costa media armata in parte supera; auriculis $9 \mathrm{~mm}$ longis, 2-3 mm latis, triangularibus, in apice adnatis, 2 vel 3 denticulis armatis in parte infera. Infructescentia terminalis, 3 spicis praedita, pedunculo communi $5 \mathrm{~mm}$ longo; syncarpiis $1.2 \mathrm{~cm}$ longis, $0.9 \mathrm{~cm}$ latis, maturis, breviter cylindraceis vel ellipsoideis vel ovatis, pedunculis $12 \mathrm{~mm}$ longis, $1.5 \mathrm{~mm}$ latis, laevibus. Baccae $2 \mathrm{~mm}$ longae, sclerenchymate-centrali angustissimo tenuissimo in pileo praeditae (?) sed fibris destitutae; stigmatibus 2, interdum 3 , areola 
stigmatica annulo destituta. Semina $1 \mathrm{~mm}$ longa, $0.4 \mathrm{~mm}$ lata in medio, \pm recta; strophiolo distincto, $0.08 \mathrm{~mm}$ vel paulo latiore; endospermio $0.25 \mathrm{~mm}$ lato; raphe distincta, 0.07 mm vel paulo minus lata. - Typus: Croft \& Lelean LAE 65528 (holo L; iso BRI, K, LAE), Bismarck Archipelago, New Ireland, Metemulai Village, west of Lavongai, 9 October 1974.

Fruit-bearing branchlets $8-20 \mathrm{~cm}$ long; internodes terete, 3-9 mm long, 3-4 mm thick, smooth. Leaves below the infructescence lanceolate, remote, 5-9 cm long, $0.7-$

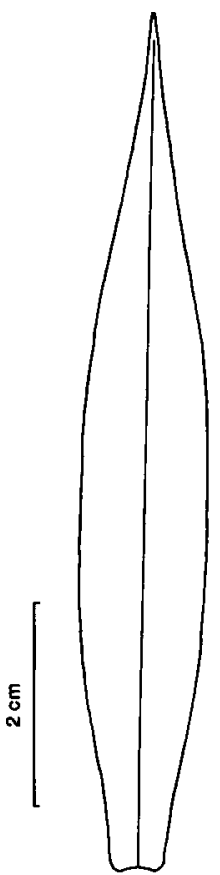

Fig. 10. Freycinetia lanceolata Huynh. Leaf flattened horizontally, viewed at the adaxial surface (auricles not shown) (Croft \& Lelean LAE 65528).

$1.3 \mathrm{~cm}$ wide in the middle part, $0.5 \mathrm{~cm}$ at the base (auricles not included), 4-5 mm acuminate, semiamplexicaul at the base, in dry state brown, membranaceous; longitudinal veins visible on the adaxial surface, \pm prominent on the abaxial surface; transverse veins indistinct on the adaxial surface, sometimes visible on the abaxial surface; margins armed from the apex almost to the sheath, prickles up to $1 / 4 \mathrm{~mm}$ long; midrib armed in the upper part, prickles up to $1 / 2 \mathrm{~mm}$ long and generally longer than those of the margins; auricles preserved in some upper leaves, triangular, 9 by $2-3$ $\mathrm{mm}$, adnate at the apex, membranaceous, brown, dull, fibrous, armed with 2 or 3 prickles in the lower part, (in the microscope) epidermis unlignified at both sides, mesophyll with one vascular bundle and several short and separate fibre strands, blade slightly compressed between the fibre strands. Infructescence terminal, 3-spiked, peduncle $5 \mathrm{~mm}$ long; syncarps short-cylindric, ellipsoid or ovate, 1.2 by $0.9 \mathrm{~cm}$, mature; peduncles 12 by $1.5 \mathrm{~mm}$, smooth. Berries $2 \mathrm{~mm}$ long, with (?) a central sclerenchyma very narrow and very thin in the pileus but without fibres; stigmas 2 , sometimes 3 , the stigmatic areola having no ring; pileus pyramidal, 0.5 $\mathrm{mm}$ long. Seeds $1 \mathrm{~mm}$ long, $0.4 \mathrm{~mm}$ wide in the middle, \pm straight; strophiole distinct, $0.08 \mathrm{~mm}$ wide or a little wider; endosperm $0.25 \mathrm{~mm}$ wide; raphe distinct, 0.07 $\mathrm{mm}$ wide or a little less, with raphide cells but without crystal cells.

Field note - Leaves semigloss, mid green above, dull light green below, fruit red when mature.

Notes -1 . The anatomy of the leaf auricles of $F$. lanceolata described above (epidermal cells all unlignified; mesophyll with several separate fibre strands) suggests that they probably disintegrated into separate fibres.

2. Freycinetia lanceolata is noteworthy by its leaf auricles, which have only short fibre strands, contrary to the general case. It appears very close to $F$. inermis (Irian Jaya). This species differs from $F$. lanceolata especially in its leaf margins which are unarmed or armed in the uppermost $5 \mathrm{~mm}$ only, and in its seeds where the strophiole, the endosperm, and the raphe are each about 1/3 of the seed width (Huynh, 2000: 293-294). 
11. Freycinetia lenifolia Huynh, spec. nov. (sect. Pleiostigma) - Fig. 11

Ramuli fructiferi internodiis $5-8 \mathrm{~mm}$ longis, $2.5 \mathrm{~mm}$ crassis, laevibus, teretibus com-
positi. Folia infra infructescentiam (10-)15-17 cm longa, $2-2.5 \mathrm{~mm}$ lata in parte media
$1.5 \mathrm{~mm}$ in basi (auriculis non inclusis), lineari-lanceolata, breviter acuminata, dissita, in
basi semiamplexicaulia; in sicco atroviridula, membranacea, flexibilia; marginibus armatis
in brevi spatio supra basim et in apice solum; costa media sparsim armata in dimidio
supero circiter; auriculis $1.2 \mathrm{~cm}$ longis, $2 \mathrm{~mm}$ latis, triangularibus, in apice adnatis,
setulosis minimum in parte supera. Infructescentia terminalis, monosyncarpica; syncarpio
$1.5 \mathrm{~cm}$ longo, $1.4 \mathrm{~cm}$ lato, maturo, subgloboso, pedunculo $1 \mathrm{~cm}$ longo, $1.5 \mathrm{~mm}$ lato, tenuiter setuloso. Baccae sclerenchymate-centrali in pileo praeditae sed fibris destitutae; stigmatibus (2-)3-4(-6), areola stigmatica annulo perspicuo cincta. Semina $1.1 \mathrm{~mm}$ longa, $0.7 \mathrm{~mm}$ lata in medio, recta, biconvexa; strophiolo distincto, $0.15 \mathrm{~mm}$ lato; endospermio 0.4 mm lato; raphe distincta, $0.15 \mathrm{~mm}$ lata. - Typus: Croft et al. LAE 68628 (holo L; iso LAE), D'Entrecasteaux Is., Fergusson Is., track between Ailuluai and Agamoia, alt. $720 \mathrm{~m}, 3$ November 1976.

Fruit-bearing branchlets $29-34 \mathrm{~cm}$ long in axis; internodes terete, 5-8 mm long, $2.5 \mathrm{~mm}$ thick, smooth. Leaves below the infructescence linear-lanceolate, remote, (10-)15-17 $\mathrm{cm}$ long, 2-2.5 mm wide in the middle part, $1.5 \mathrm{~mm}$ at the base (auricles not included), short-acuminate, semiamplexicaul at the base, in dry state dark greenish, membranaceous, flexible, partially striate on the adaxial surface; longitudinal veins distinct on the abaxial surface, less so on the adaxial surface; transverse veins invisible; margins armed only just above the base and at the apex, lower prickles thin, setiform, up to 1.5-2 mm long, upper prickles very minute; midrib sparsely armed in the upper half; auricles preserved in some upper leaves, triangular, $1.2 \mathrm{~cm}$ by $2 \mathrm{~mm}$, triangular, adnate at the apex, setulose at least in the upper part, membranaceous, brown, dull, fibrous, (in the microscope) epidermis unlignified at one side but slightly lignified at the other side, mesophyll with one vascular bundle and several long and separate fibre strands, blade not compressed between the fibre strands. Infructescence terminal, monosyncarpic; syncarp subglobose, 1.5 by $1.4 \mathrm{~cm}$, mature, peduncle $1 \mathrm{~cm}$ by $1.5 \mathrm{~mm}$, finely setulose. Berries with a central sclerenchyma in the pileus but without fibres; stigmas (2-)3-4(-6), the stigmatic areola with a perspicuous and shining ring. Seeds straight, biconvex, $1.1 \mathrm{~mm}$ long, $0.7 \mathrm{~mm}$ wide in the middle; strophiole distinct, 0.15 $\mathrm{mm}$ wide; endosperm $0.4 \mathrm{~mm}$ wide; raphe distinct, 0.15 $\mathrm{mm}$ wide, with raphide cells but without crystal cells.

Field notes - Hill forest. Leaves semigloss, dark green, fruit orange. Local name Dina Dina.

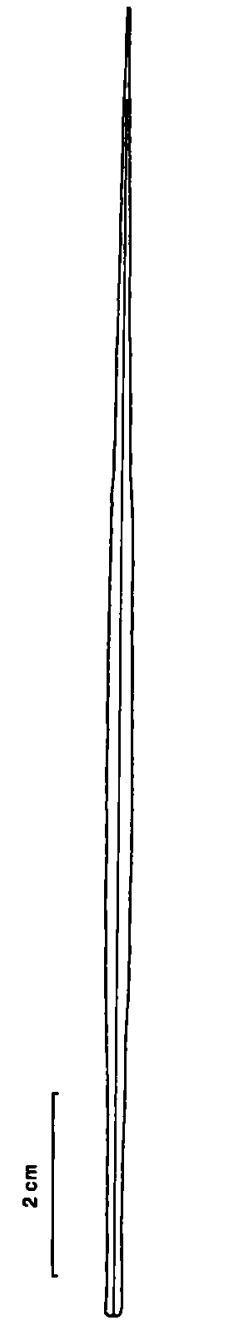

Fig. 11. Freycinetia lenifolia Huynh. Leaf flattened horizontally, viewed at the adaxial surface (the auricles are not shown) (Croft et al. $L A E$ 68628). 
Notes - 1. The anatomy of the leaf auricles of $F$. lenifolia described above (epidermal cells not or only slightly lignified; mesophyll with several long and separate fibre strands) suggests that they probably disintegrated into separate fibres.

2 . Apparently there are no species very closely related to $F$. lenifolia. This species shows some resemblance with $F$. boluboluensis, described above. This latter species differs from $F$. lenifolia especially in its berries which do not have a ring around the stigmatic areola, its leaves which are shorter but almost three times as broad, and in its leaf auricles whose fibre strands in the mesophyll form a single band across the auricle width.

\section{Freycinetia nakanaiensis Huynh, spec. nov. (sect. Pleiostigma) - Fig. 12}

Ramulus fructifer internodiis $1-1.5 \mathrm{~cm}$ longis, $7 \mathrm{~mm}$ crassis, laevibus, trigonis compositus. Folia infra infructescentiam 9-10 cm longa, 1.8-2 cm lata in medio $8 \mathrm{~mm}$ in basi (auriculis non inclusis), lanceolata, 3-4 mm acuminata, dissita, in basi \pm amplexicaulia; in sicco brunneola, subcoriacea, patentia; marginibus armatis in brevi spatio in apice solum; costa media armata in 1/3 supera circiter; auriculis $2.5-3 \mathrm{~cm}$ longis, $5 \mathrm{~mm}$ latis, in separatis fibris solutis. Infructescentia terminalis, 4 spicis praedita, pedunculo communi $2 \mathrm{~cm}$ longo; syncarpiis $2 \mathrm{~cm}$ longis, $1.5 \mathrm{~cm}$ latis, maturis, ellipticis, pedunculis $2 \mathrm{~cm}$ longis, $3 \mathrm{~mm}$ latis, scabridis. Baccae $5 \mathrm{~mm}$ longae, sclerenchymate-centrali in pileo praeditae sed fibris destitutae; stigmatibus $2-4$, arte aggregatis igitur indistinctis, areola stigmatica annulo destituta. Semina $1.2 \mathrm{~mm}$ longa, $0.5 \mathrm{~mm}$ lata in medio, recta; strophiolo indistincto; endospermio $0.35 \mathrm{~mm}$ lato; raphe angustissima. - Typus: Vinas LAE 59723 (holo LAE), Bismarck Archipelago, New Britain, by the bank of lake in Nakanai Plateau, alt. 1610 m, 11 November 1975.

Fruit-bearing branchlet partially preserved, the remnant $24 \mathrm{~cm}$ long; internodes trigonous, $1-1.5 \mathrm{~cm}$ long, $7 \mathrm{~mm}$ thick, smooth. Leaves below the infructescence lanceolate, remote, 9-10 cm long, 1.8-2 $\mathrm{cm}$ wide at the middle, $8 \mathrm{~mm}$ at the base (auricles not included), 3-4 mm acuminate, \pm amplexicaul at the base, in dry state brownish, subcoriaceous, densely striate on both surfaces, patent; longitudinal veins indistinct; transverse veins invisible; margins armed in a short course at the apex only, prickles up to 1/3 mm long; midrib armed in the upper third; auricles almost all preserved, $2.5-3 \mathrm{~cm}$ by $5 \mathrm{~mm}$, membranaceous, brownish, dull, in separate fibres, (in the microscope) epidermis unlignified at one side but slightly lignified at the other side, mesophyll with several long, thick and separate fibre strands, blade not compressed between the fibre strands. Infructescence terminal, 4-spiked, peduncle $2 \mathrm{~cm}$ long; syncarps elliptic, 2 by $1.5 \mathrm{~cm}$, mature, peduncles $2 \mathrm{~cm}$ by $3 \mathrm{~mm}$, scabrid. Berries $5 \mathrm{~mm}$ long, with a central

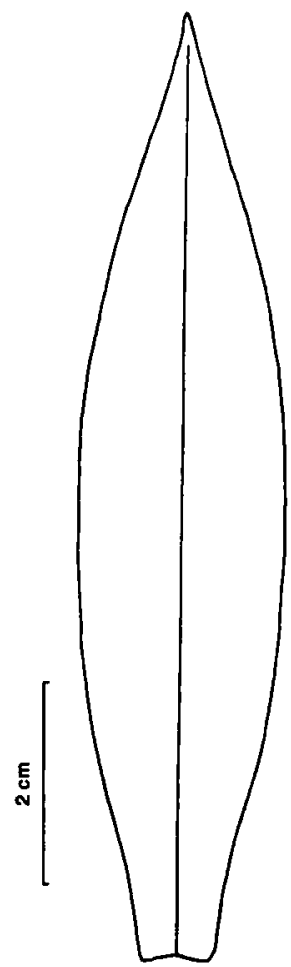

Fig. 12. Freycinetia nakanaiensis Huynh. Leaf flattened horizontally, viewed at the adaxial surface (auricles not shown) (Vinas LAE 59723). 
sclerenchyma in the pileus but without fibres; stigmas 2-4, closely aggregated hence indistinct, the stigmatic areola having no ring. Seeds straight, $1.2 \mathrm{~mm}$ long, $0.5 \mathrm{~mm}$ wide in the middle; strophiole indistinct; endosperm $0.35 \mathrm{~mm}$ wide; raphe very narrow, with raphide cells but without crystal cells.

Field notes - Young Nothofagus forest with Gleichenia dominating the ground layer. Creeping herb, leaves gloss, dark green above, mid green below, fruit dark green, changed to deep red when ripe.

Notes -1 . The anatomy of the leaf auricles of $F$. nakanaiensis described above (epidermal cells not or only slightly lignified; mesophyll with several long and separate fibre strands) accounts for their disintegration into separate fibres. Since the stigmas are indistinct, their numbers on berries were also determined by observing the numbers of fertilisation canals in the transverse sections of pilei (see Huynh, 2000: 284).

2. Freycinetia nakanaiensis is noteworthy in that the longitudinal veins of its leaves are indistinct on the abaxial surface, contrary to the general case.

3. Apparently there are no species very closely related to $F$. nakanaiensis. This species shows some resemblance with $F$. salamauensis (Papua New Guinea). This latter species differs from $F$. nakanaiensis especially in its leaves which are up to $3 \mathrm{~cm}$ wide but of the same length, and armed in the apical part and the basal part; in particular, its mature syncarps are three times as long $(6 \mathrm{~cm})$, and its seeds have a wide and distinct strophiole (Merrill \& Perry, 1939: 152).

\title{
13. Freycinetia normanbyensis Huynh, spec. nov. (sect. Pleiostigma) - Fig. 13
}

\begin{abstract}
Ramulus fructifer internodiis $1-1.5 \mathrm{~cm}$ longis, $5-6 \mathrm{~mm}$ crassis, dense tenuiter granularibus, teretibus compositus. Folia infra infructescentiam $12-14 \mathrm{~cm}$ longa, $3-3.5 \mathrm{~cm}$ lata in medio $8 \mathrm{~mm}$ in basi (auriculis non inclusis), elliptico-lanceolata; in ramulis sterilibus $14-20 \mathrm{~cm}$ longa, $2-2.5 \mathrm{~cm}$ lata in medio $8 \mathrm{~mm}$ in basi (auriculis non inclusis), oblongolanceolata; 5-8 $\mathrm{mm}$ acuminata, dissita, in basi semiamplexicaulia; in sicco brunnea, submembranacea, patentia; marginibus armatis ex apice ad vaginam, saepe inermibus in parte media; costa media armata in parte supera; auriculis $1 \mathrm{~cm}$ longis, $4 \mathrm{~mm}$ latis, triangularibus, in apice adnatis, in separatis fibris solutis. Infructescentia terminalis cum laterales in ramulo fructifero praesentes, omnes infructescentiae 3 spicis praeditae; infructescentiis lateralibus axe $1.5-2 \mathrm{~cm}$ longo suffultis, qui in basi folio unico sursum versus prophyllis et bracteis composito est; syncarpiis $3 \mathrm{~cm}$ longis, $2 \mathrm{~cm}$ latis, maturis, ellipticis, pedunculis $2-3 \mathrm{~cm}$ longis, $2-2.5 \mathrm{~mm}$ latis, laevibus, raro sparsim scabridis. Baccae $5 \mathrm{~mm}$ longae, sclerenchymate-centrali in pileo praeditae sed fibris destitutae; stigmatibus (3-)4-5(-8-10), areola stigmatica annulo perspicuo cincta; pileo $3 \mathrm{~mm}$ longo, pyramidali. Semina $1.2 \mathrm{~mm}$ longa, $0.6 \mathrm{~mm}$ lata in medio, sublunata; strophiolo distincto, $0.25 \mathrm{~mm}$ lato; endospermio $0.3 \mathrm{~mm}$ lato; raphe subnulla, ut maximum 0.05 mm lata. - Typus: Croft \& Marsh LAE 71173 (holo L), D'Entrecasteaux Is., Normanby Is., NE of Bwasiaiai, alt. $450 \mathrm{~m}, 4$ December 1977.
\end{abstract}

Fruit-bearing branchlet $22 \mathrm{~cm}$ long; internodes terete, $1-1.5 \mathrm{~cm}$ long, 5-6 mm thick, densely and finely granular. Leaves below the infructescence elliptic-lanceolate, 12$14 \mathrm{~cm}$ long, 3-3.5 $\mathrm{cm}$ wide at the middle, $8 \mathrm{~mm}$ at the base (auricles not included), in sterile branchlets, oblong-lanceolate, remote, $14-20 \mathrm{~cm}$ long, $2-2.5 \mathrm{~cm}$ wide at the middle, $8 \mathrm{~mm}$ at the base (auricles not included), 5-8 $\mathrm{mm}$ acuminate, semiamplexicaul at the base, in dry state brown, submembranaceous, patent; longitudinal veins distinct on the adaxial surface, hardly visible on the abaxial surface; transverse veins invisible; margins armed from the apex to the sheath but frequently unarmed in the middle part, 


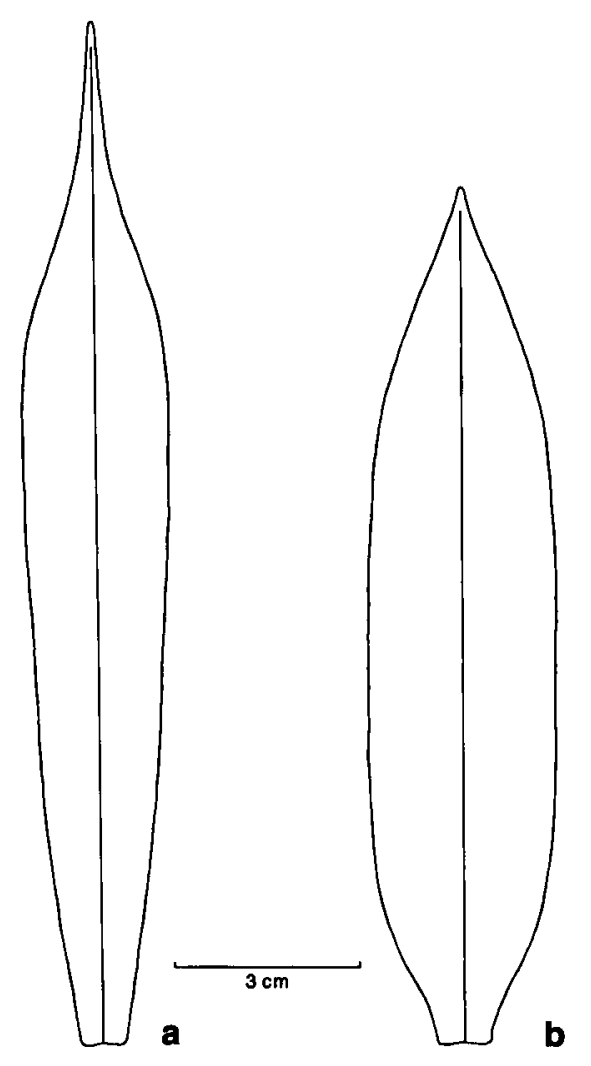

Fig. 13. Freycinetia normanbyensis Huynh. Leaves flattened horizontally, viewed at the adaxial surface (auricles not shown): a. sterile branchlet; $b$. fruit-bearing branchlet (Croft \& Marsh LAE 71173).

prickles up to $1.5 \mathrm{~mm}$ long near the base, minute above; midrib armed in the upper part, prickles generally sparse; auricles preserved in some upper leaves, triangular, $1 \mathrm{~cm}$ by $4 \mathrm{~mm}$, adnate at the apex, membranaceous, brown, dull, 1-veined, fibrous, in separate fibres, (in the microscope) epidermis unlignified at both sides, mesophyll with one vascular bundle and several short and separate fibre strands, blade compressed between the fibre strands. Infructescence terminal and lateral, both at the same fruitbearing branchlet, 3 -spiked; lateral infructescences $1.5-2 \mathrm{~cm}$ long, with a single leaf at the base and prophylls and bracts above; syncarps elliptic, 3 by $2 \mathrm{~cm}$, mature; peduncles $2-3 \mathrm{~cm}$ by $2-2.5 \mathrm{~mm}$, smooth, rarely sparsely scabrid. Berries $5 \mathrm{~mm}$ long, with a central sclerenchyma in the pileus but without fibres; stigmas (3-)4-5(-8-10), the stigmatic areola with a perspicuous and shining ring; pileus $3 \mathrm{~mm}$ long, pyramidal. Seeds sublunate, $1.2 \mathrm{~mm}$ long, $0.6 \mathrm{~mm}$ wide in the middle; strophiole distinct, 0.25 $\mathrm{mm}$ wide; endosperm $0.3 \mathrm{~mm}$ wide; raphe almost nil, at most $0.05 \mathrm{~mm}$ wide, with raphide cells but without crystal cells.

Field notes - Lower montane forest, moderately dry, Eucalyptopsis dominant. Leaves waxy, dark green above, mid green below, fruit orange.

Notes -1 . The anatomy of the leaf auricles of $F$. normanbyensis described above (epidermal cells all unlignified; mesophyll with several separate fibre strands) accounts for their disintegration into separate fibres. 
2. Freycinetia normanbyensis is noteworthy by the following features: its leaf auricles have only short fibre strands, contrary to the general case; the longitudinal veins of its leaves are more distinct on the adaxial surface than on the abaxial surface, contrary to the general case; in its seeds, the strophiole is very distinct while the raphe is almost nil. In particular, its lateral infructescences have a leaf at the base of their axis, a very rare feature. Also, it is to date the only known species in New Guinea that has both a granular stem and leaves $3-3.5 \mathrm{~cm}$ wide.

14. Freycinetia novobritannica Huynh, spec. nov. (sect. Oligostigma) - Fig. 14

Internodia ramorum 1-2 cm longa, 5-6 mm crassa, laevia, teretia. Folia $25-28 \mathrm{~cm}$ longa, $2.5-3.5 \mathrm{~cm}$ lata in medio $6-7 \mathrm{~mm}$ in basi (auriculis non inclusis), lanceolata, $5 \mathrm{~mm}$ acuminata, dissita, in basi semiamplexicaulia; in sicco atroviridula, chartacea, flexibilia;

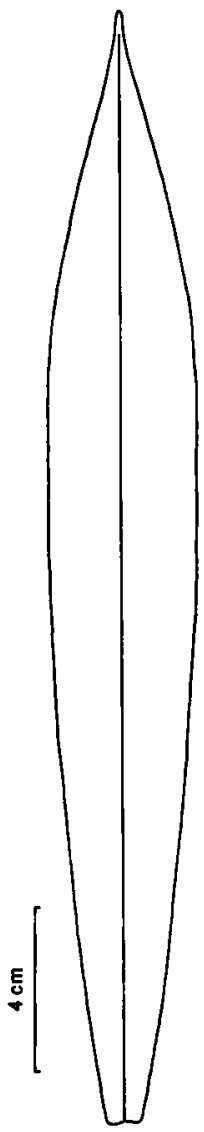

Fig. 14. Freycinetia novobritannica Huynh. Leaf flattened horizontally, viewed at the adaxial surface (the auricles not shown) (Sohmer et al. LAE 75303). marginibus sparsim armatis in brevi spatio in apice solum, interdum inermibus; costa media sparsim armata in apice solum sed in spatio longiore quam marginibus; auriculis $6 \mathrm{~cm}$ longis, $5 \mathrm{~mm}$ latis, bis volutis. Infructescentia lateralis, 3 spicis praedita, axe $2 \mathrm{~cm}$ longo suffulta, 5 vel 6 internodiis composito, prophyllis in basi praedito sed foliis destituto; syncarpiis $2.5 \mathrm{~cm}$ longis, $1.5 \mathrm{~cm}$ latis, maturis, cylindraceis, pedunculis $1.5 \mathrm{~cm}$ longis, $2 \mathrm{~mm}$ latis, laevibus. Baccae sclerenchymate-centrali in pileo praeditae sed fibris destitutae; stigmatibus 2, interdum 3, areola stigmatica annulo destituta. Semina $1.3 \mathrm{~mm}$ longa, $0.7 \mathrm{~mm}$ lata in medio, recta; strophiolo, endospermio, raphe omnibus ca. 1/3 latitudinis seminis latis, sed strophiolo paulo latiore quam raphe. - Typus: Sohmer et al. LAE 75303 (holo L; iso LAE), Bismarck Archipelago, New Britain, left bank of Kapiura River about $1 \mathrm{~km}$ south of confluence with the Aum River, alt. $20 \mathrm{~m}, 16$ May 1979.

Internodes of branches terete, 1-2 cm long, 5-6 mm thick, smooth. Leaves lanceolate, remote, $25-28 \mathrm{~cm}$ long, $2.5-3.5 \mathrm{~cm}$ wide at the middle, $6-7 \mathrm{~mm}$ at the base (auricles not included), $5 \mathrm{~mm}$ acuminate, semiamplexicaul at the base, in dry state dark greenish, chartaceous, flexible, striate on both surfaces; longitudinal veins visible on both surfaces but more so on the abaxial surface; transverse veins invisible; margins sparsely armed at the apex only, sometimes unarmed, prickles at most $1 / 3 \mathrm{~mm}$ long; midrib also armed at the apex only but for a longer stretch than the margins; auricles preserved in some leaves, $6 \mathrm{~cm}$ by $5 \mathrm{~mm}$, membranaceous, dark brown, dull, rolled up twice, (in the microscope) epidermis unlignified at both sides, mesophyll with two vascular bundles and several short and separate fibre strands, blade strongly compressed between the fibre strands. Infructescence lateral, 3spiked, the axis $2 \mathrm{~cm}$ long, formed of 5 or 6 internodes, 
with prophylls at the base but no leaves; syncarps cylindric, 2.5 by $1.5 \mathrm{~cm}$, mature, peduncles $1.5 \mathrm{~cm}$ by $2 \mathrm{~mm}$, smooth. Berries with a central sclerenchyma in the pileus but without fibres; stigmas 2 , sometimes 3 , the stigmatic areola having no ring. Seeds straight, $1.3 \mathrm{~mm}$ long, $0.7 \mathrm{~mm}$ wide in the middle; strophiole, endosperm, and raphe each about a third of the seed width, but strophiole a little wider than raphe; in the raphe, raphide cells present but crystal cells absent.

Field note - Lowland, alluvial, rain forest, Pometia pinnata the dominant tree.

Notes -1 . The anatomy of the leaf auricles of $F$. novobritannica described above (epidermal cells all unlignified; mesophyll with several separate fibre strands) suggests that they probably disintegrated into separate fibres along the two vascular bundles which extend from the base almost to the apex. These leaf auricles are most unusual: they roll up twice along their axis while they still adhere entirely on the leaf, and make almost two circles in transverse section. Such leaf auricles have not been observed in any other known species of Freycinetia. In addition, they have only short fibre strands, contrary to the general case.

2. Freycinetia novobritannica appears closest to F. madangensis (Papua New Guinea), which also belongs to sect. Oligostigma and also has lateral infructescences. This latter species differs from $F$. novobritannica especially in its leaves which are spathulato-subcuspidate, its leaf auricles which do not roll up when dry, and in its berries which do not have a central sclerenchyma (Huynh, 2000: 286, f. 3).

\section{Freycinetia relegata Huynh, spec. nov. (sect. Oligostigma) - Fig. 15}

Folia infra infructescentiam $60-80 \mathrm{~cm}$ longa, $2-2.5 \mathrm{~cm}$ lata in medio $1.6 \mathrm{~cm}$ prope basim $1.8 \mathrm{~cm}$ in basi (auriculis non inclusis), ensiformia, $3-4 \mathrm{~cm}$ caudata, imbricata, in basi amplexicaulia; in sicco viridula, submembranacea in dimidio supero, subcoriacea in infero, in 3-4 cm infra caudam valde revoluta ceterum patentia; marginibus armatis ex apice ad vaginam; costa media armata in 1/4-1/3 supera circiter; auriculis $8-9 \mathrm{~cm}$ longis, $1.3 \mathrm{~cm}$ latis, in apice adnatis et oblique truncatis. Infructescentia terminalis, 3 spicis praedita, pedunculo communi ut videtur $8 \mathrm{~cm}$ longo; syncarpiis $5 \mathrm{~cm}$ longis, 1.2 $\mathrm{cm}$ latis, immaturis, oblongis, pedunculis $5 \mathrm{~cm}$ longis, $3 \mathrm{~mm}$ latis, laevibus. Baccae filiformes, sclerenchymate-centrali in pileo et longissimis fasciculis fibrarum, ex apice ad basim non interruptis, non fusiformibus/ellipticis, praeditae; stigmatibus 2, distinctis et oppositis, raro 4, areola stigmatica annulo perspicuo cincta. - Typus: Gideon LAE 73235 (holo LAE), Louisiade Archipelago, Sudest Is., Base of Mt Riu, alt. $300 \mathrm{ft}$, 6 March 1979.

Leaves below the infructescence ensiform, imbricate, $60-80 \mathrm{~cm}$ long, $2-2.5 \mathrm{~cm}$ wide at the middle, $1.6 \mathrm{~cm}$ near the base, $1.8 \mathrm{~cm}$ at the base (auricles not included), $3-4 \mathrm{~cm}$ caudate, amplexicaul at the base, in dry state greenish, submembranaceous in the upper half, subcoriaceous in the lower half, tessellate and not striate on the abaxial surface, partially tessellate and striate on the adaxial surface, strongly revolute along $3-4 \mathrm{~cm}$ beneath the cauda while patent elsewhere; longitudinal veins distinct on both surfaces; transverse veins distinct on the abaxial surface, partially so on the adaxial surface; margins armed from the apex to the sheath, prickles up to $1 \mathrm{~mm}$ long near the base, minute above; midrib armed in the upper quarter to upper third, prickles \pm as long as those in the nearby margins; auricles all preserved, $8-9$ by $1.3 \mathrm{~cm}$, adnate and obliquely truncate at the apex, submembranaceous, dark brown, slightly nerved, densely and finely striate, dull, smooth, (in the microscope) at one side both epidermis and 
hypodermis unlignified, at the other side epidermis almost entirely lignified and hypodermis in two lignified layers, mesophyll with vascular bundles and several long and separate fibre strands, blade not compressed between the fibre strands. Infructescence terminal, 3-spiked, peduncle apparently $8 \mathrm{~cm}$ long; syncarps oblong, 5 by 1.2 $\mathrm{cm}$, immature, peduncles $5 \mathrm{~cm}$ by $3 \mathrm{~mm}$, smooth. Berries filiform, with a central sclerenchyma in the pileus and very long fibre bundles which extend from the apex to the base and are not fusiform/elliptic; stigmas 2 , distinct and opposite, rarely 4 , the stigmatic areola with a perspicuous and shining ring.

Field notes - Vatica dominated forest, on ridge top. Leaves green, flowers bright orange.

Notes - 1. Freycinetia relegata is a species of sect. Filiformicarpae B.C. Stone, which is a section described by Stone (1968: 366) who derived it (and other sections he described) from sect. Oligostigma Warb. It is remarkable by its leaves, which are strongly revolute along 3$4 \mathrm{~cm}$ beneath the cauda while they are patent elsewhere. Also, with a hypodermis with two lignified cell-layers, as described above, its leaf auricles will probably not disintegrate into separate fibres.

2. Freycinetia relegata appears closest to $F$. rossellana, described below, which is also found in the Louisiade Archipelago and also belongs to sect. Filiformicarpae. The two species differ especially in their leaves, syncarps, and syncarp peduncles. In $F$. rossellana: the leaves are $35-43 \mathrm{~cm}$ long and patent from the base to the apex; the syncarps are $3.7 \mathrm{~cm}$ long when mature; the syncarp peduncles are $2.5 \mathrm{~cm}$ long. In $F$. relegata: the leaves are $60-80 \mathrm{~cm}$ long and strongly revolute for $3-4 \mathrm{~cm}$ beneath the cauda while they are patent elsewhere; the syncarps must be longer when mature since

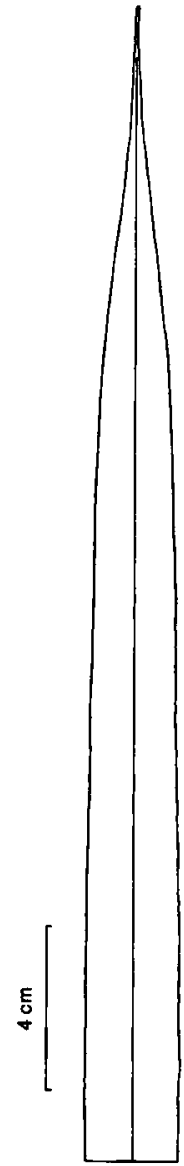

Fig. 15. Freycinetia relegata Huynh. Upper part of leaf flattened horizontally, viewed at the adaxial surface (Gideon LAE 73235). they are $5 \mathrm{~cm}$ long but still immature; the syncarp peduncles are $5 \mathrm{~cm}$ long.

3. Freycinetia relegata is named in allusion to its occurrence in Sudest Is., quite remote from New Guinea, the main centre of diversity of the genus in Papuasia. Also, it is the only species of sect. Filiformicarpae in Sudest Island.

\section{Freycinetia rossellana Huynh, spec. nov. (sect. Oligostigma) - Fig. 16}

Folia infra infructescentiam $35-43 \mathrm{~cm}$ longa, $1.4-1.6 \mathrm{~cm}$ lata in $1 / 4$ supera $1.2 \mathrm{~cm}$ prope basim $1.4 \mathrm{~cm}$ in basi (auriculis non inclusis), ensiformia, $2-3 \mathrm{~cm}$ caudata, imbricata, in basi amplexicaulia; in sicco brunnea, (sub)membranacea, patentia; marginibus armatis in circiter dimidio infero et $1 / 4$ supera; costa media armata in 1/4 supera circiter; auriculis $5 \mathrm{~cm}$ longis, 5-6 mm latis, in apice adnatis et oblique truncatis. Infructescentia terminalis, 3 spicis praedita, pedunculo communi ut videtur $4 \mathrm{~cm}$ longo; syncarpiis $3.7 \mathrm{~cm}$ longis, 
$2.2 \mathrm{~cm}$ latis, maturis, ellipsoideis, pedunculis $2.5 \mathrm{~cm}$ longis, $3 \mathrm{~mm}$ latis, laevibus. Baccae $9 \mathrm{~mm}$ longae, filiformes, sclerenchymate-centrali in pileo et longissimis fasciculis fibrarum, ex apice ad basim non interruptis, non fusiformibus vel ellipticis, praeditae; stigmatibus 2 , distinctis et oppositis, interdum 4, areola stigmatica annulo perspicuo cincta. Semina $1.1 \mathrm{~mm}$ longa, $0.3 \mathrm{~mm}$ lata in medio, recta; strophiolo indistincto; raphe $0.05 \mathrm{~mm}$ lata. - Typus: Brass 28300 (holo LAE), Louisiade Archipelago, Rossel Is., Abaleti, alt. $50 \mathrm{~m}, 3$ October 1956.

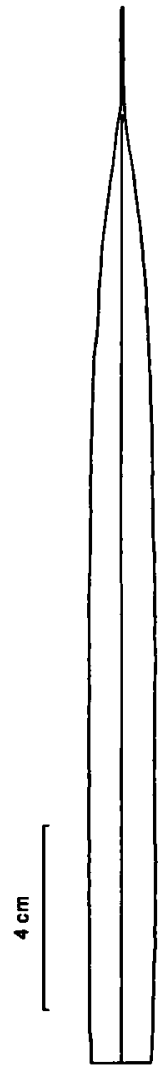

Fig. 16. Freycinetia rossellana Huynh. Upper part of leaf flattened horizontally, viewed at the adaxial surface (Brass 28300).

Leaves below the infructescence ensiform, imbricate, $35-43 \mathrm{~cm}$ long, $1.4-1.6 \mathrm{~cm}$ wide at the upper quarter, $1.2 \mathrm{~cm}$ near the base, $1.4 \mathrm{~cm}$ at the base (auricles not included), $2-3 \mathrm{~cm}$ caudate, amplexicaul at the base, in dry state brown, (sub)membranaceous, striate on both surfaces, tessellate on the abaxial surface, patent; longitudinal veins distinct on both surfaces but more so on the abaxial surface; transverse veins distinct on the abaxial surface, invisible on the adaxial surface; margins armed in the lower half and upper quarter, prickles up to $1 \mathrm{~mm}$ long near the base, at most $1 / 4$ mm long above; midrib armed in the upper quarter, prickles \pm as long as those in the nearby margins; auricles all preserved, $5 \mathrm{~cm}$ by $5-6 \mathrm{~mm}$, adnate and obliquely truncate at the apex, membranaceous, brown, nerved, dull, smooth, (in the microscope) at one side both epidermis and hypodermis unlignified, at the other side epidermis almost entirely lignified and hypodermis in one strongly lignified layer, mesophyll with vascular bundles and several long and separate fibre strands, blade not compressed between the fibre strands. Infructescence terminal, 3-spiked, peduncle apparently $4 \mathrm{~cm}$ long; syncarps ellipsoid, 3.7 by $2.2 \mathrm{~cm}$, mature, peduncles $2.5 \mathrm{~cm}$ by $3 \mathrm{~mm}$, smooth. Berries filiform, $9 \mathrm{~mm}$ long, with a central sclerenchyma in the pileus and very long fibre bundles which extend from the apex to the base and are not fusiform/elliptic; stigmas 2, distinct and opposite, sometimes 4 , the stigmatic areola with a perspicuous and shining ring. Seeds $1.1 \mathrm{~mm}$ long, $0.3 \mathrm{~mm}$ wide in the middle, straight; strophiole indistinct; raphe $0.05 \mathrm{~mm}$ wide, with raphide cells but without crystal cells.

Field notes - Sunny edge of rain forest. Scrambling to $2 \mathrm{~m}$.

Notes -1 . The fact that the leaf auricles of $F$. rossellana have a hypodermis which is entirely and strongly lignified, as described above, suggests that they will probably not disintegrate into separate fibres.

2. Freycinetia rossellana appears closest to $F$. relegata. Both are found in the Louisiade Archipelago and are members of sect. Filiformicarpae, as mentioned above, under $F$. relegata. The two species differ especially in their leaves, syncarps, and syncarp peduncles (see under $F$. relegata). 
17. Freycinetia woodlarkensis Huynh, spec. nov. (sect. Pleiostigma) - Fig. 17

Ramuli fructiferi internodiis $2 \mathrm{~cm}$ longis, $5 \mathrm{~mm}$ crassis, laevibus compositi. Folia infra infructescentiam $15-17 \mathrm{~cm}$ longa, (2-)2.5-2.8(-3.2) $\mathrm{cm}$ lata in medio $6-8 \mathrm{~mm}$ in basi (auriculis non inclusis), lanceolata, 2-3 mm acuminata, perspicue dissita, in basi semiamplexicaulia; in sicco brunnea, membranacea, patentia; marginibus armatis ex apice fere ad vaginam, interdum inermibus in parte media; costa media armata in 1/3-2/3 superis; auriculis $1.5-2 \mathrm{~cm}$ longis, $4 \mathrm{~mm}$ latis, in separatis fibris solutis. Infructescentia terminalis, 3 spicis praedita, pedunculo communi $5 \mathrm{~mm}$ longo; syncarpiis $5 \mathrm{~cm}$ longis, $2.5 \mathrm{~cm}$ latis, maturis, cylindricis, pedunculis $15 \mathrm{~mm}$ longis, $2 \mathrm{~mm}$ latis, laevibus. Baccae $5 \mathrm{~mm}$ longae, sclerenchymate-centrali in pileo praeditae sed fibris destitutae; stigmatibus 3-4(-5), areola stigmatica annulo destituta. Semina $1.2 \mathrm{~mm}$ longa, $0.7 \mathrm{~mm}$ lata in medio, \pm recta; strophiolo distincto, $0.17 \mathrm{~mm}$ lato; endospermio $0.22 \mathrm{~mm}$ lato; raphe $0.3 \mathrm{~mm}$ lata. - Typus: Brass 28709 (holo L; iso LAE), Woodlark Is., Kulumadau, alt. 100 m, 11 November 1956.

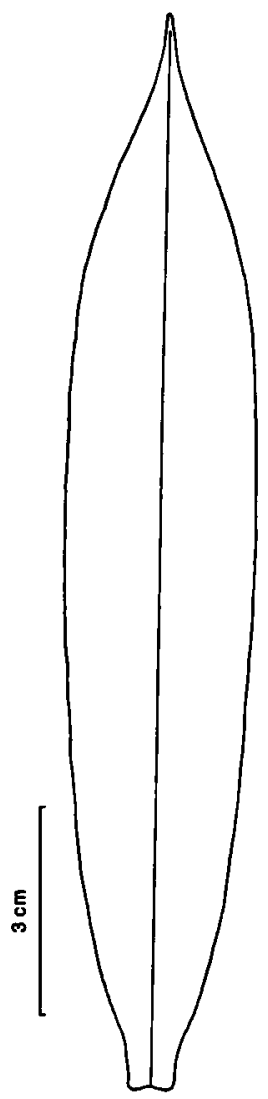

Fig. 17. Freycinetia woodlarkensis Huynh. Leaf flattened horizontally, viewed at the adaxial surface (the auricles not shown) (Brass 28709).
Fruit-bearing branchlets partially preserved, the remnant $20 \mathrm{~cm}$ long; internodes $2 \mathrm{~cm}$ long, $5 \mathrm{~mm}$ thick, smooth. Leaves below the infructescence lanceolate, perspicuously remote, $15-17 \mathrm{~cm}$ long, (2-) 2.5-2.8 $(-3.2) \mathrm{cm}$ wide at the middle, $6-8 \mathrm{~mm}$ at the base (auricles not included), 2-3 mm acuminate, semiamplexicaul at the base, in dry state brown, membranaceous, mostly tessellate on the abaxial surface, striate on the adaxial surface, patent; longitudinal veins perspicuous on the abaxial surface, visible on the adaxial surface; transverse veins visible on the abaxial surface, invisible on the adaxial surface; margins armed from the apex almost to the sheath, sometimes unarmed in the middle part, prickles up to $2 / 5 \mathrm{~mm}$ long; midrib armed in the upper $1 / 3-2 / 3$, prickles generally longer than those in the nearby margins; auricles preserved in some upper leaves, $1.5-2 \mathrm{~cm}$ by $4 \mathrm{~mm}$, membranaceous, pale brown, dull, densely fibrous, in separate fibres, (in the microscope) epidermis unlignified at both sides, mesophyll with vascular bundles and several separate fibre strands most of these being long and several-layered, blade slightly compressed between the fibre strands. Infructescence terminal, 3-spiked, peduncle $5 \mathrm{~mm}$ long; syncarps 5 by $2.5 \mathrm{~cm}$, mature, cylindric, peduncles 15 by $2 \mathrm{~mm}$, smooth. Berries $5 \mathrm{~mm}$ long, with a central sclerenchyma in the pileus but without fibres; stigmas 3 or 4 (or 5), the stigmatic areola having no ring. Seeds \pm straight, $1.2 \mathrm{~mm}$ long, $0.7 \mathrm{~mm}$ wide in the middle; strophiole distinct, $0.17 \mathrm{~mm}$ wide; endosperm $0.22 \mathrm{~mm}$ wide; raphe $0.3 \mathrm{~mm}$ wide, with raphide cells but without crystal cells.

Field notes - Common in rain forest. Scrambling to several meters, fruitheads up to 5 by $2.5 \mathrm{~cm}$, red when ripe. 
Notes -1 . The anatomy of the leaf auricles of $F$. woodlarkensis described above (epidermal cells all unlignified; mesophyll with several long and separate fibre strands) accounts for their disintegration into separate fibres.

2. Freycinetia woodlarkensis seems to be the first species of Freycinetia observed in Woodlark Island. It appears closest to $F$. concolor (Papua New Guinea). This latter species differs from $\boldsymbol{F}$. woodlarkensis especially in its leaves whose abaxial surface is not tessellate, its berries which do not have a central sclerenchyma, and in its seeds where the raphe, the endosperm, and the strophiole are each about 1/3 the seed width (Huynh, 2000: 287-288).

\section{ACKNOWLEDGEMENTS}

The author expresses his thanks to the directors of the Nationaal Herbarium Nederland, Universiteit Leiden branch (L), Lae Herbarium (LAE), Royal Botanic Gardens Kew (K), and Queensland Herbarium (BRI), for the loan of materials.

\section{REFERENCES}

Huynh, K.-L. 1995. A new species of Freycinetia (Pandanaceae) from the Society Islands - New subgenus and new sections. Candollea 50: 231-245.

Huynh, K.-L. 1996. The genus Freycinetia (Pandanaceae) in New Guinea (part 1). Bot. Jahrb. Syst. 118: 529-545.

Huynh, K.-L. 1997. The genus Freycinetia Gaudich. (Pandanaceae) in the Solomon Islands. Candollea 52: 359-382.

Huynh, K.-L. 1999. The genus Freycinetia (Pandanaceae) in New Guinea (part 2). Bot. Jahrb. Syst. 121: 149-186.

Huynh, K.-L. 2000. The genus Freycinetia (Pandanaceae) in New Guinea (part 3). Candollea 55: 283-306.

Merrill, E.D. \& L.M. Perry. 1939. On the Brass collections of Pandanaceae from New Guinea. J. Arnold Arbor. 20: 139-186.

Stone, B.C. 1968. Materials for a monograph of Freycinetia Gaud. IV. Subdivision of the genus, with fifteen new sections. Blumea 16: 361-372.

Warburg, O. 1900. Pandanaceae. In: A. Engler (ed.), Das Pflanzenreich 3 (= iv.9). Engelmann, Leipzig. 